Elsevier required licence: (c) 2019

This manuscript version is made available under the CC-BY-NC-ND 4.0 license

http://creativecommons.org/licenses/by-nc-nd/4.0/

The definitive publisher version is available online at https://doi.org/10.1016/j.watres.2019.115081 


\title{
Urban beaches are environmental hotspots for antibiotic resistance following rainfall
}

\author{
Richard L. Carney ${ }^{a}$, Maurizio Labbate ${ }^{b}$, Nachshon Siboni ${ }^{a}$, Kaitlin A. Tagg ${ }^{\text {c, d }}$, Simon M. Mitrovic ${ }^{b}$, \\ Justin R. Seymour ${ }^{\mathrm{a}, *}$ \\ ${ }^{a}$ Climate Change Cluster, University of Technology Sydney, Australia \\ ${ }^{\mathrm{b}}$ School of Life Sciences, University of Technology Sydney, Australia \\ c Westmead Institute for Medical Research, University of Sydney, NSW, Australia \\ d IHRC, Inc., Atlanta, GA, USA
}

\section{A R T I C L E INFO}

Article history:

Received 15 May 2019

Received in revised form 9 September 2019

Accepted 10 September 2019

Available online xxx

\section{Keywords:}

Antibiotic resistance

Storm-water

Sewage

Microbial ecology

Quantitative PCR

Beach

\begin{abstract}
A B S T R A C T
To reveal the occurrence and mechanisms for dispersal of antibiotic resistance (AbR) among the microbial assemblages inhabiting impacted coastal environments, we performed a weekly, two-year duration time-series study at two urban beaches between 2014 and 2016. We combined quantitative PCR and multiplex PCR/ reverse line blot techniques to track patterns in the occurrence of $31 \mathrm{AbR}$ genes, including genes that confer resistance to antibiotics that are critically important antimicrobials for human medicine. Patterns in the abundance of these genes were linked to specific microbial groups and environmental parameters by coupling qPCR and 16S rRNA amplicon sequencing data with network analysis. Up to 100-fold increases in the abundance of several AbR genes, including genes conferring resistance to quinolones, trimethoprim, sulfonamides, tetracycline, vancomycin and carbapenems, occurred following storm-water and modelled wet-weather sewer overflow events. The abundance of AbR genes strongly and significantly correlated with several potentially pathogenic bacterial OTUs regularly associated with wastewater infrastructure, such as Arcobacter, Acinetobacter, Aeromonas and Cloacibacterium. These high-resolution observations provide clear links between storm-water discharge and sewer overflow events and the occurrence of AbR in the coastal microbial assemblages inhabiting urban beaches, highlighting a direct mechanism for potentially significant AbR exposure risks to humans.
\end{abstract}

\section{Introduction}

The rapid global rise of antibiotic resistance (AbR) has primarily occurred as a consequence of the misuse and over-use of therapeutic antibiotics in medicine and agriculture (Sarmah et al., 2006; Van Boeckel et al., 2014; Witte, 1998). As a result, the efficacy of many life-saving antibiotics has diminished (O'Neill, 2016; Wright, 2007), leading to increased incidence of untreatable infections in humans (Hawkey and Jones, 2009; Michael et al., 2014). While the bulk of research into the spread of AbR has focused on clinical settings (Wright, 2010), AbR has become increasingly considered a "One Health" issue - the concept that human health is connected to the health of animals and the natural environment (Robinson et al., 2016). This is because AbR can emerge and move between humans, animals and wider environments (Pehrsson et al., 2016), with the global spread of AbR facilitated by the movement of the human population, the transport of livestock and food products (Foley and Lynne, 2008; Sarmah et al., 2006) and insufficiently treated waste streams (Baquero et al., 2008).

Anthropogenic waste streams contribute to the environmental spread of AbR in two ways. First, excreted therapeutic antibiotics

\footnotetext{
* Corresponding author. University of Technology Sydney, PO Box 123 Broadway, NSW, 2007, Australia.

Email address: justin.seymour@uts.edu.au (J.R. Seymour)
}

present in the urine and feces of animals and humans (Rang, 2016), not destroyed during wastewater treatment processes (Michael et al., 2013), may persist at concentrations sufficient to select for AbR microbes within natural bacterial communities when introduced into aquatic environments (Baquero et al., 2008; Chow et al., 2015; Tello et al., 2012). Second, anthropogenic waste streams deposit clinically important AbR microbes and their associated genes and genetically-linked mobile genetic elements (MGEs) such as plasmids, transposons and integrons directly into the environment (Chamosa et al., 2017; Gillings et al., 2008; Kummerer, 2009; Marti et al., 2014). This creates a scenario where transmission of resistance genes from human and animal pathogens into endemic aquatic microbial communities (Taylor et al., 2011) or into the microbiomes of exposed humans (Hehemann et al., 2010) can occur.

Urban coastal beaches represent an important interface for human exposure to microbial contaminants. These environments are heavily used by humans for recreation and food supply (Clark and Johnston, 2017), but are also potentially subject to large quantities of human and animal waste streams (Stewart et al., 2008). The transport of potentially pathogenic enteric microbes from urban waste streams into coastal waters is a major public health concern due to high incidence of waterborne infections, and associated healthcare costs (Collier et al., 2012). There are four primary mechanisms by which urban waste streams transport human and animal enteric microbes into coastal surface waters. Firstly, sewer overflow (including dry and wet 
weather events) enter the storm-water system, bypass wastewater sanitation processes and directly transport human enteric microbes into coastal waters (McLellan et al., 2015). Secondly, untreated sewage can enter into environmental waters due to sewer blockages and leaks. Thirdly, following heavy rainfall, runoff from impervious urban surfaces such as streets, roofs and parks wash non-human enteric microbes that may originate from domestic animals and birds (Bucci et al., 2017; Van Dyke et al., 2010) into drains that discharge into coastal receiving waters. Fourthly, both human and animal enteric microbes that persist in storm-water infrastructure can be scoured from stormwater surfaces during intense flow and subsequently flushed into beaches (McLellan et al., 2015; Vandewalle et al., 2012). Notably, because urban storm-water conveyance environments are frequently exposed to a range of anthropogenic pollutants, including trace concentrations of antibiotics, and heavy metals that co-select for AbR, genes that confer resistance to antibiotics can be selected for in waste stream microbes (Czekalski et al., 2012; Marchaim et al., 2012). Therefore, while the negative influence of enteric pathogens has typically been considered the central human health issue within coastal environments (Turgeon et al., 2011), the transmission of AbR genes poses an additional threat, with emerging evidence that regular users of coastal ecosystems (e.g. surfers) can assimilate AbR microbes into their microbiome (Leonard et al. 2015, 2018).

Coastal water quality monitoring programs typically only target a narrow selection of indicator organisms (Boehm and Sassoubre, 2014), and thus generally overlook antibiotic resistant microbes and AbR genes that can enter natural waterways via storm-water systems. However, the dissemination of AbR genes from waste streams into coastal habitats could have profound consequences for human health (Leonard et al., 2018). Investigations into the reservoirs and pathways of AbR across different environments are therefore needed to understand the processes that influence the movement of AbR microbes and genes, and to develop strategies for combating the growing global AbR crisis (Wright, 2010). Within this context, we performed a two year duration, high-resolution microbial time-series study at two coastal sites in Sydney, Australia's largest city, with the goal of defining the temporal dynamics and mechanisms for input of AbR genes in urban beach environments.

\section{Materials and methods}

\subsection{Study sites, data and sample collection}

Two study sites were selected according to contrasting levels of exposure to storm-water and sewage pollution, with one highly impacted and one relatively unaffected site selected. Foreshore Beach, situated within the partially enclosed waters of Botany Bay $\left(33.95^{\circ} \mathrm{S}\right.$, $151.9^{\circ} \mathrm{E}$ ) (Supplementary Information Fig. 1), is subject to the influence of multiple storm-water outlets and is frequently exposed to high levels of urban storm-water discharge as well as periodic sewer overflows from upstream overflow outlets (NSW Office of Environment and Heritage, 2015), which occur during periods of intense rainfall, but may also occur in dry weather due to mechanical failures. Furthermore, Foreshore Beach is adjacent to Sydney Airport, and a commercial port, which may contribute storm water runoff and contaminants. In contrast, Maroubra Beach $\left(33.95^{\circ} \mathrm{S}, 151.25^{\circ} \mathrm{E}\right)$ is directly exposed to the Pacific Ocean and has higher levels of hydrodynamic flushing, while also experiencing substantially less impact from storm-water inputs (NSW Office of Environment and Heritage, 2015) (Supplementary Information Fig. 1).
During the study period (2nd May 2014 to 29th April 2016), rainfall data was retrieved from the Australian Bureau of Meteorology website (www.bom.gov.au/climate/data) using the nearest gauge station to each sampling site. Storm-water inputs deposit low salinity urban runoff into the beach water, which results in a decrease of electrical conductivity (EC). Decreases in EC were therefore used here to distinguish sampling time points as either storm-water impacted or non-impacted samples. Additionally, at Foreshore Beach, modelled data was used to estimate the total weekly volume of wet weather sewer overflow (WWSO), which was released at Mill Pond, an upstream sewage overflow discharge point, during the study period. Here, WWSOs were defined as the release of excess, dilute wastewater (containing a mixture of stormwater and sewage) from the wastewater system in heavy rain. Conveyance of WWSO into environmental waters avoids backflow into residential and commercial buildings. Modelled WWSO volumes, generated using the Model for Urban Sewers (MOUSE) software package (Institute, 1999) were obtained from Sydney Water (the water authority responsible for the operation of Sydney's wastewater systems) as rates of WWSO (measured in $\mathrm{m}^{3} 15 \mathrm{~min}^{-1}$ ). These values were summed across the week preceding each sampling event. WWSO events were subsequently defined as samples collected within 7 days of a modelled WWSO from the Mill Pond overflow point into Botany Bay.

Sampling was conducted at each site on a weekly basis (every Friday morning between 0800 and 1100 AEST) over the course of 24 months, leading to the establishment of two time-series, each comprising 104 time points. At each site, all samples were collected from near to the shore-line $(<1.5 \mathrm{~m}$ depth $)$, in triplicates spread from the left-most, middle and right-most areas where swimmers and surfers use the water. Physico-chemical parameters, including temperature, $\mathrm{pH}, \mathrm{EC}$ and dissolved oxygen (DO) were measured in situ using a WTW Multiprobe meter (Multi 3430, Germany). For analysis of dissolved inorganic nutrients, including $\mathrm{NH}_{4}, \mathrm{NO}_{\mathrm{x}}$ and $\mathrm{PO}_{4}$, triplicate $50 \mathrm{~mL}$ samples were collected and filtered through a $0.45 \mu \mathrm{m}$ filter (Sartorius Stedim Biotech) and immediately transported to the laboratory on ice. Samples were stored at $-80^{\circ} \mathrm{C}$ within $2 \mathrm{~h}$ of sample collection for later nutrient analysis. For bacterial enumeration, triplicate $1 \mathrm{~mL}$ water samples were collected from each $5 \mathrm{~L}$ water sample, filtered through a $100 \mu \mathrm{m}$ mesh, fixed with glutaraldehyde ( $2 \%$ final concentration) and snap frozen in liquid nitrogen for subsequent flow cytometric (FCM) analysis. Microbial DNA was retrieved by filtering triplicate $2.5 \mathrm{~L}$ samples through $0.22 \mu \mathrm{m}$ pore-size membrane filters (Millipore) using a peristaltic pump. Filters were stored at $-80^{\circ} \mathrm{C}$ for subsequent DNA extraction.

\subsection{Nutrient analysis}

Concentrations of $\mathrm{NH}_{4}, \mathrm{NO}_{\mathrm{x}}$ and $\mathrm{PO}_{4}$ were determined via a colorimetric analysis using the Lachat Quickchem QC8500 Automated Ion Analyser (LACHAT Instruments, USA) in accordance with the manufacturer's guidelines. Internal controls, including addition of spiked recovery samples and blanks were included to monitor the consistency of instrument performance. The resulting data were transferred and interpreted using Omnion version 3 software (LACHAT Instruments, USA).

\subsection{Bacterial cell enumeration}

Prior to analysis, samples were quick-thawed in warm water and stained with SYBR Green I nucleic acid stain (1:10,000 final dilution; Molecular Probes, Eugene, OR, USA) (Marie et al., 1997; Gasol and Del Giorgio, 2000; Seymour et al., 2007). Fluorescent reference 
beads ( $1 \mu \mathrm{m}$ in diameter, yellow-green; Molecular Probes) were added to each sample as an internal concentration and fluorescence standard in a final concentration of $10^{5} \mathrm{~mL}^{-1}$. Samples were analysed using an LSRII flow cytometer (Becton Dickinson, San Jose, CA, USA) and bacterial populations were discriminated according to cell side scatter (SSC) and SYBR Green fluorescence (Seymour et al., 2007). Data-files were analysed using WinMDI 2.9 software (WinMDI, Joseph Trotter, Salk Institute for Biological Studies, La Jolla, CA, USA).

\subsection{DNA extraction and $16 S$ rRNA-amplicon sequencing}

Microbial DNA was extracted from $0.22 \mu \mathrm{m}$ membrane filters using the Powerwater DNA isolation Kit (MoBio Laboratories, Inc) in accordance with the manufacturer's instructions. DNA quantity and purity was evaluated using a Nanodrop-1000 Spectrophotometer. Patterns in bacterial community diversity and composition throughout the two-year time series were characterised using 16S rRNA amplicon sequencing. The V1-V3 variable region of the 16S rRNA gene was amplified using the primers 27f 5'-AGRGTTTGATCMTGGCTCAG-3' and 519r 5'-GTNTTACNGCGGCKGCTG-3'. Sequencing was performed using the Illumina MiSeq platform following the manufacturer's guidelines. Raw data files in FASTQ format are deposited in the NCBI Sequence Read Archive (SRA) with the study accession number (in process, to be provided prior to submission) under Bioproject number PRJNA4209011.

16S rRNA gene sequences were analysed using the QIIME pipeline (Caporaso et al., 2010; Kuczynski et al., 2012). Briefly, paired-end DNA sequences were joined and de novo Operational Taxonomic Units (OTUs) were defined at $97 \%$ sequence identity using UCLUST (Edgar et al., 2011). Chimeric sequences were detected using ChimeraSlayer (Haas et al., 2011) and filtered from the dataset. Taxonomy was assigned against the SILVA v128 database using the BLAST option in QIIME. Sequences were rarefied to the same depth to remove the effect of sampling effort upon analysis, and Shannon's Index was calculated within QIIME to quantify $\beta$ diversity. All Chloroplast OTU's were filtered out of the bacterial data-set and transferred to a separate OTU table, where taxonomy was subsequently assigned against the PhytoREF database (Decelle et al., 2015; Needham and Fuhrman, 2016) using QIIME (Caporaso et al., 2010). The relative abundance of each chloroplast OTU was calculated after normalising chloroplast sequences to total sequence reads within each sample.

\subsection{Quantitative PCR ( $q P C R)$}

Quantitative PCR (qPCR) was used to track patterns in the absolute abundance of the class 1 integron integrase gene (intI1), which has been shown to be an excellent proxy for anthropogenic pollution in natural habitats (Gillings et al., 2015), as well as five genes that confer resistance to broad spectrum, first line and last resort antibiotics. These included tetA, sulI, qnrS, dfrAl, and vanB, which confer resistance to tetracyclines, sulfonamides, fluoroquinolones, trimethoprim, and vancomycin respectively (Supplementary Information Table 1). These genes were selected for intensive, weekly monitoring using qPCR because preliminary PCRs performed on water samples before embarking on the 2 year time series showed that these genes were present and therefore good for tracking temporal trends and stormwater impacts. Furthermore, robust assays were already established, and have been employed in other studies of AbR genes in natural environments (Berglund et al. 2014, 2015).
qPCR was run in triplicate for each assay, amounting to a total of 3,744 analyses across the two 24 month time-series. Quantification of the relative abundance of intIl and the five AbR genes was achieved by normalising gene copy numbers to total volume of water sample filtered for DNA extraction.

To create qPCR standards for intI1, dfrA1, qnrS, sulI, tetA and $v a n B$, the respective amplicon was PCR amplified from genomic DNA acquired from Foreshore Beach and cloned using the pGEM-T Easy Vector System (Promega) according to the manufacturer's instructions. To confirm that correct inserts were cloned, we extracted plasmids from chosen colonies, amplified the fragment using PCR and ran fragment on gel using electrophoresis to confirm the size. Purified plasmid (GenElute Plasmid Miniprep Kit, Sigma) or PCR products (Isolate II PCR and Gel Kit, Bioline) were quantified using Qubit (Invitrogen) and stored at $-20^{\circ} \mathrm{C}$.

qPCR was performed using the BIORAD CFX384 Touch $^{\mathrm{TM}}$ Real-Time PCR Detection System ${ }^{\mathrm{TM}}$ and gene copies were calculated for each amplicon by plotting against their respective standard curve using BIORAD CFX Manager software. All qPCR tests were run using three technical replicates, consisting of $5 \mu \mathrm{l}$ reaction volumes containing $2.5 \mu \mathrm{l}$ iTaq UniverSYBR Green SMX 2500®, $0.1 \mu 1$ nuclease free water, $0.2 \mu \mathrm{M}$ of each forward and reverse primer and $2 \mu \mathrm{l}$ of diluted (1:10) DNA template. Negative control samples were run with every plate for detection of contamination, and a $16 \mathrm{~S}$ rRNA qPCR assay (Nadkarni et al., 2002) was also run for all samples to confirm that inhibitors were not preventing amplification of genes. Calibration curves were run with every plate, with all reagent and plate preparation conducted using an epMotion ${ }^{\circledR} 50751$ Automated Liquid Handling System. Cycling parameters and determined limit of quantification for each qPCR assay are provided in Supplementary Information Table 1 . To confirm that each primer pair produced only a single specific product, a melting curve was added to the end of every qPCR assay for each set of primers.

\subsection{Multiplex $P C R(m P C R)$ and reverse line blot $(R L B)$ hybridization}

DNA samples collected from Foreshore Beach were screened for additional AbR genes (see Supplementary Information Table 1 for complete list of primers and targeted AbR genes) of regional clinical relevance using multiplex polymerase reaction with reverse line blot (mPCR/RLB) hybridization (Agyekum et al., 2016; Ginn et al., 2013; Kong and Gilbert, 2006). Briefly, amine-labelled oligonucleotide probes targeting $26 \mathrm{AbR}$ genes were covalently bound to a nylon membrane in a 45 -lane miniblotter. Biotin-labelled $\mathrm{mPCR}$ products plus blanks and positive controls were loaded perpendicularly, followed by hybridization at $60^{\circ} \mathrm{C}$. Streptavidin-peroxidase conjugate and chemiluminescent substrate were used for detection of the membrane-bound mPCR amplicons.

\subsection{Statistical analysis}

Bacterial abundance, diversity and community composition was compared using Analysis of Similarity (ANOSIM) in the PRIMER6 + PERMANOVA package (Anderson et al., 2007; Anderson, 2001). Similarity percentage analysis (SIMPER) was employed to identify and rank the top $25 \%$ of bacterial OTU's that contributed most to storm-water and sewage impacted and dry period communities at both beaches.

Exploration of statistically significant correlation patterns between bacteria, phytoplankton, environmental parameters and AbR genes was conducted within each site, across the 104 week time-series using Extended Local Similarity Analysis (eLSA) (Xia, 2011). eLSA 
was used to identify statistically significant correlations, including time-lagged interactions, between OTUs, AbR gene abundances and environmental variables, for subsequent construction of microbial networks. Only pairwise interactions that occurred across $10 \%$ or more of the time points were included, and each remaining interaction was subjected to 1000 permutations to calculate statistical significance ( $p$ value) and the false detection rate (q value). Interactions where $p>0.001$ and $q>0.01$ were excluded to reduce the risk of Type I and Type II errors. Resultant data defined all statistically significant co-occurrence events, including those that occurred with -2 to +2 time-interval time lags. eLSA data was ultimately visualised using the edge-weighted spring embedded function in Cytoscape 3 software package, using the local similarity (LS) value of pairwise correlations to define the length of edges connecting nodes.

To determine temporal relationships between environmental variables and the abundance of AbR genes measured using qPCR (absolute abundance) and $\mathrm{mPCR} / \mathrm{RLB}$ (presence/absence), selected pairwise co-occurrence and time-lagged correlations were measured in $\mathrm{R}$ using the cross correlation factor (CCF) method (Wessa (2017)). $\mathrm{CCF}$ is a method for estimating the degree to which two variables are correlated across a time series, also allowing for the detection of time-lagged correlations. Resultant data was visualised in CCF graphs showing the temporal correlation relationships across the 104 week time-series.

\section{Results \& discussion}

3.1. Storm-water and wet weather sewer overflow events alter physicochemical conditions and microbial community abundance and structure

Every year, an estimated three trillion litres of storm-water is discharged from Australian urban centers into aquatic habitats (SECRC and Committee) 2015). Here, we defined storm-water events at the Foreshore Beach and Maroubra Beach sites as periods where a $10 \%$ reduction in electrical conductivity $(\mathrm{EC})\left(<48 \mathrm{mS} \mathrm{cm}^{2}\right)$ from mean levels was recorded, as EC levels below this threshold coincided consistently with rainfall events. Moreover, in many urbanised settings, intense rainfall events sometimes result in wet weather sewer overflow (WWSO) events. In Sydney, Australia's largest city, it is estimated that 143 WWSOs occurred across 10 coastal WWTPs from 2014 to 2015 , resulting in approximately 27,964 ML of WWSO, as modelled by the Trunk Wastewater System Model Update, Re-calibration and Annual Reporting Procedure (Sydney Water Corporation, 2015). The WWSO events that occurred at Foreshore Beach during the course of this study were characterised by the modelled total volume of WWSO released from an upstream overspill point within seven days of each sample occasion.

Storm-water events were observed at both sampling sites, although at varying levels of intensity and duration. Cross correlation factor (CCF) analysis revealed that rainfall correlated significantly with a decline in EC at the impacted Foreshore Beach site (Supplementary Information Fig. 2), during the 16 storm-water events observed during the two-year study (Fig. 2). The duration of impact of storm-water events at this site ranged between 1 and 4 weeks (Fig. 2). In contrast, rainfall did not correlate significantly with declines in EC at Maroubra Beach (Supplementary Information Fig. 2), with only 2 notable storm-water events recorded at this site. Notably, the modelled WWSO events coincided with 10 of the 16 storm-water events at Foreshore Beach (Fig. 1), with modelled WWSO volume ranging in magnitude from $4,193 \mathrm{~m}^{3} \mathrm{week}^{-1}$ to $465,438 \mathrm{~m}^{3}$ week $^{-1}$.
The highest recorded nutrient concentrations coincided with WWSO events (Supplementary Information Fig. 3).

At Foreshore Beach, storm-water events led to significant increases in the concentration of all measured inorganic nutrients $\left(\mathrm{NH}_{4}\right.$, $\mathrm{NOx}$ and $\mathrm{PO}_{4}$; Supplementary Information Fig. 3; $\mathrm{r}=0.429$, $\mathrm{p}=0.001)$. However, this pattern was not observed at Maroubra Beach ( $p>0.05$ ), where fewer storm-water events occurred, and mixing and tidal flushing likely disperses runoff rapidly. Similarly, both bacterial abundance and diversity (Shannon's Index) remained relatively stable at Maroubra Beach $(p>0.01)$, but varied significantly $(p<0.01)$ at Foreshore Beach, with highest bacterial abundances (Supplementary Information Fig. 4) and diversity (data not shown) corresponding with periods of rainfall that resulted in storm-water input and modelled WWSO. We propose that the rapid increases in bacterial diversity (measured using Shannon's diversity, data not shown) recorded at Foreshore Beach during storm-water inputs are reflective of the allochthonous input of enteric and pipe-dwelling microbes during storm-water and WWSO events, suggesting that the observed increases in abundance at this site during these times occurred as a consequence of these inputs rather than the growth of endemic marine microbes.

The composition of bacterial communities changed significantly between dry periods and storm-water input events at Foreshore Beach $(r=0.184, p=0.017$, perm $=999)$, and even more strongly between dry periods and modelled WWSO events $(r=0.999, p=0.010$, perm $=999)$. However, significant changes in bacterial composition were not observed at Maroubra Beach $(\mathrm{p}>0.05)$. Following storm-water events, bacterial communities at Foreshore Beach were 53.2\% dissimilar to those observed during dry periods, while input from WWSO led to further dissimilarity (63.2\%) among microbial assemblages.

While bacterial communities at Maroubra Beach largely retained a marine signature throughout the 2 year time-series, where archetypal marine groups including Pelagibacter and Synechococcus dominated, storm-water events at Foreshore Beach led to a marked shift in bacterial assemblage structure from one dominated by marine microbes to one resembling enteric and storm-water pipe associated communities (Millar and Raghavan, 2017). During dry periods, the Foreshore Beach assemblage was predominantly comprised of marine bacterial groups, including Pelagibacter (8.18\%), Rhodobacteraceae $(4.94 \%)$ and Synechococcus $(3.79 \%)$. The significant $(\mathrm{p}<0.05)$ dissimilarity between bacterial assemblages during the dry period and storm-water events was principally attributed to reduced relative abundance of some of these marine groups, including Pelagibacter (3.21\%), Actinomarina (3.17\%), Synechococcus (2.47\%) and Rhodobacteraceae $(2.22 \%)$. Bacterial communities present during modelled WWSO periods were most dissimilar to dry period communities, due to increased presence of bacterial groups that are often associated with human waste streams (Fisher et al., 2014; Sauer et al., 2011) including two Arcobacter OTUs (contributing 4.14\% and 3.57\% respectively to dissimilarity), Cloacibacterium (3.01\%), Thiomicrospira $(2.76 \%)$, Anaerospora (1.79\%) and Acinetobacter (1.05\%). These bacterial groups were not detected or contributed $<1 \%$ of total bacterial communities during dry periods.

The shift in bacterial assemblage structure away from a marine community following storm-water events at Foreshore Beach was further confirmed by application of eLSA and network analysis. Using data generated from the eLSA pipeline, we detected statistically significant co-occurrence and time lagged relationships between specific bacterial OTUs and periods of storm-water and modelled WWSO input. At Foreshore Beach, storm-water input negatively correlated with 151 OTUs assigned to key marine taxa, including 35 phototrophic eukaryote OTUs, 13 Flavobacteraceae and 11 


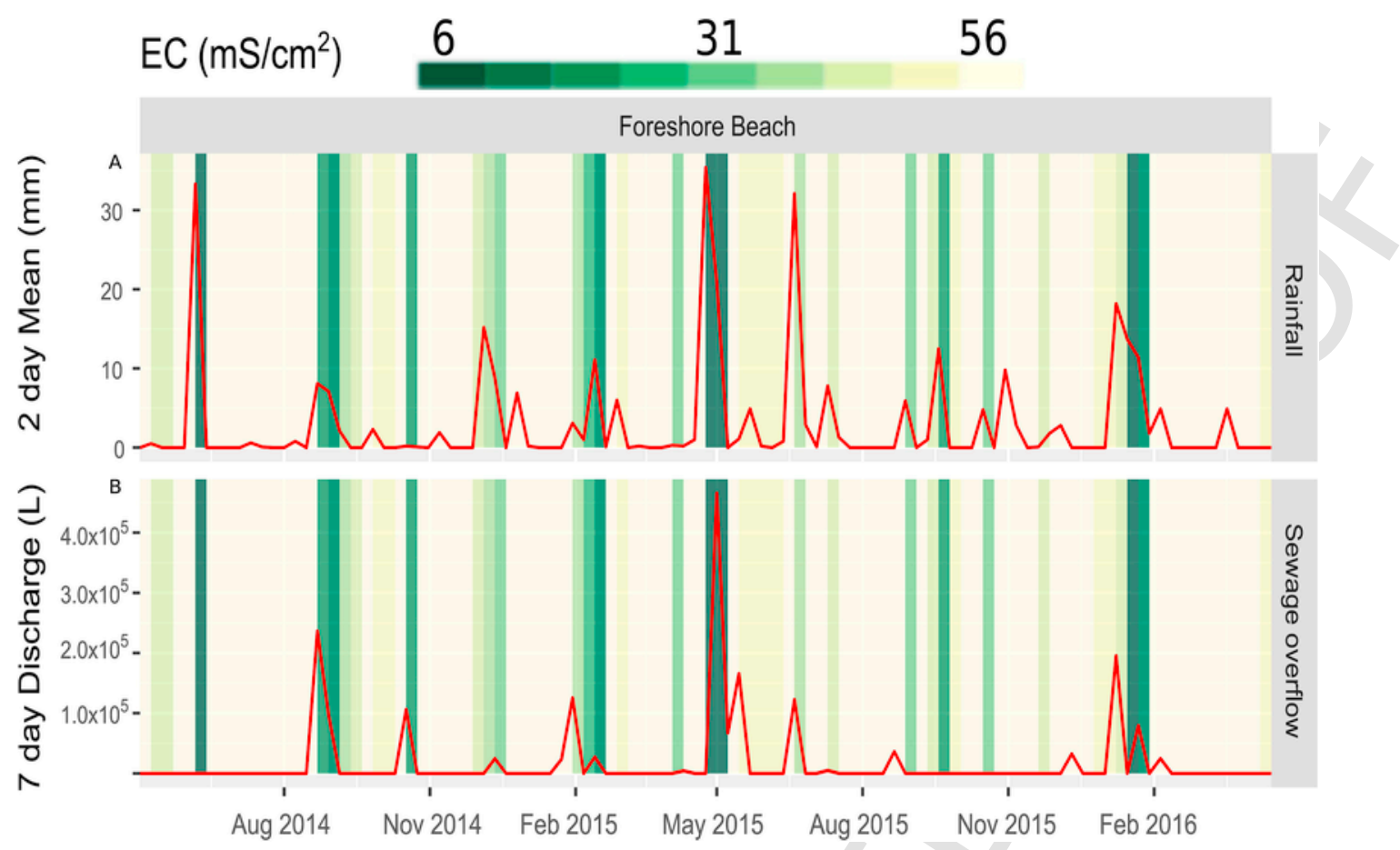

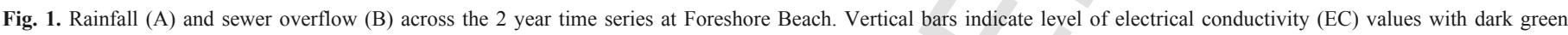

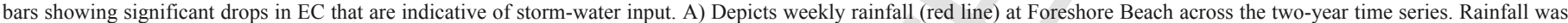

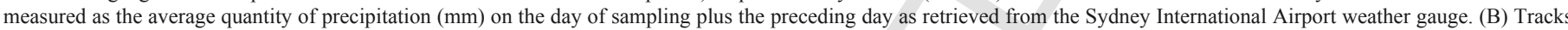

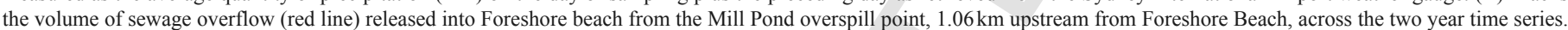

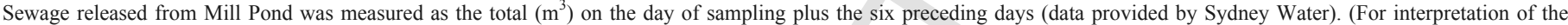
references to color in this figure legend, the reader is referred to the Web version of this article.)

Rhodobacteraceae OTUs (Fig. 2A). In contrast, 64 OTUs were positively correlated with storm-water events, with the strongest of these correlations involving archetypal sewage and pipe-dwelling bacterial groups (Fisher et al., 2014; Vandewalle et al., 2012), including (in descending order of correlative strength) Lachnospiraceae, Bacteroides, Cloacibacterium, Acinetobacter and Aeromonadaceae (Fig. 2A). The composition of bacterial communities during periods of WWSO also exhibited a similarly weakened marine signature (Fig. 2A), with strong correlations between the extent of modelled WWSO volume and the occurrence of OTUs within wastewater associated taxa including Acinetobacter, Bacteroides, Cloacibacterium and Arcobacter. These results demonstrate a clear temporal partitioning of microbial communities at Foreshore Beach, where distinct microbial assemblage structure was observed following storm-water and modelled WWSO events relative to dry periods. Notably, these temporal shifts in community structure were much less evident at Maroubra Beach, where storm-water events were less significant.

\subsection{Storm-water and WWSO events increase the abundance of AbR genes}

A significant co-occurrence and one week time-lag between storm-water and the absolute abundance (gene copies $\mathrm{L}^{-1}$ ) of intII was observed at both Maroubra Beach and Foreshore Beach (Supplementary Information Fig. 5) and modelled WWSO input and intIl at Foreshore Beach, indicating that concentrations of intIl remained above base line levels for up to one week after storm-water and WWSO input. This gene has previously been employed as a molecular marker for anthropogenic pollution in terrestrial, aquatic and marine environments (Hardwick et al., 2008), where its presence can be indicative of contamination by sewage, heavy metals and disinfec- tants, and it can act as a proxy for AbR gene occurrence (Gillings et al., 2015; Koczura et al., 2016).

Across the two-year time-series, mean intIl concentrations were detected at low, unexpectedly similar baseline concentration at both Foreshore Beach $\left(6.93 \times 10^{3}\right.$ gene copies $\left.\mathrm{L}^{-1}\right)$ and Maroubra Beach $\left(5.31 \times 10^{3}\right.$ gene copies $\left.\mathrm{L}^{-1}\right)$. However, intIl abundance increased 1-2 orders of magnitude at Foreshore Beach during storm-water (mean $1.33 \times 10^{5}$ gene copies $\mathrm{L}^{-1}$ ) and modelled WWSO events (mean 4.03 x $10^{5}$ gene copies $\mathrm{L}^{-1}$ ) (Fig. 3 ). These patterns indicate that a background level of intI1-carrying microbes is a consistent component of marine bacterial communities at both sites. However, storm-water and modelled WWSO input events at Foreshore Beach led to a substantial increase in the abundance of this gene, which is consistent with evidence that it is an accurate indicator of anthropogenic impact (Gillings et al., 2015).

eLSA revealed strong correlations between intII abundance and storm-water and modelled WWSO events, as well as to the abundance of AbR genes including sulI ( $\mathrm{LS}=0.52, \mathrm{p}=<0.001)$, tet $A(\mathrm{LS}=0.49$, $\mathrm{p}=<0.001), d f r A 1(\mathrm{LS}=0.44, \mathrm{p}=<0.001)$ and $q n r S(\mathrm{LS}=0.43, \mathrm{p}=$ $<0.001)$. The correlations between intIl and AbR genes detected in this study support the notion that intIl is a good proxy for the presence of antibiotic resistance genes (Gillings et al., 2008; Muziasari et al., 2014).

Weekly patterns in the abundance of five AbR genes that confer resistance to several classes of antibiotics that are included in the World Health Organisation's "most critically important antimicrobials for human medicine list" (WHO, 2017) were tracked during the 2 year time series. Notably, all AbR genes, with the exception of $v a n B$, were detectable at base-line levels, in concentrations between $10^{2}$ to $10^{4}$ gene copies $\mathrm{L}^{-1}$ at both beaches. Importantly, the occurrence of each of these AbR genes increased dramatically in conjunction with 


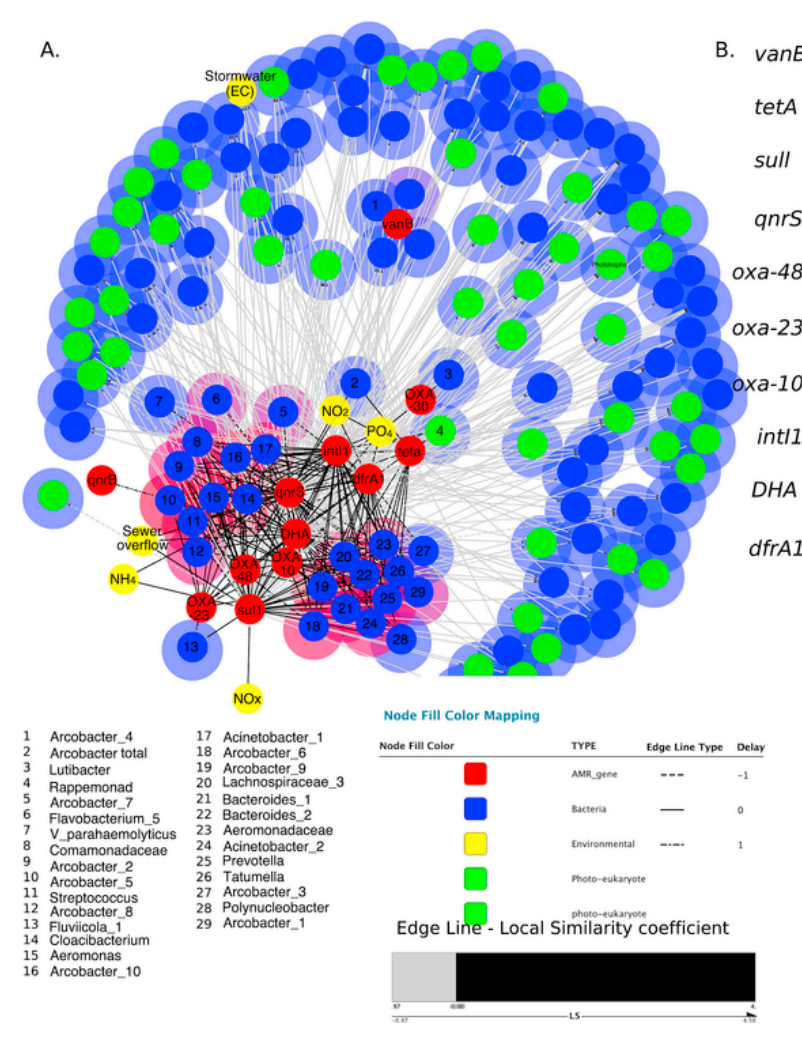

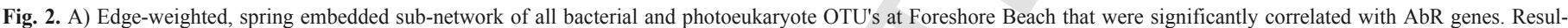

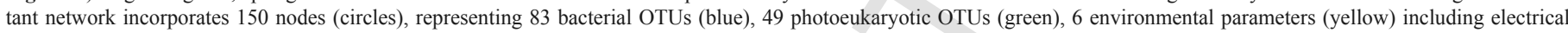

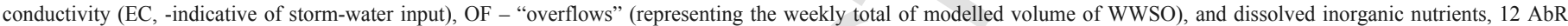

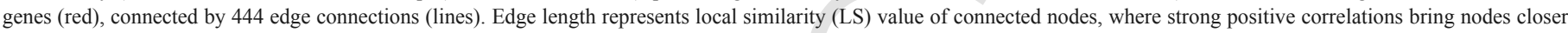

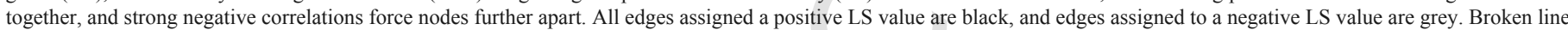

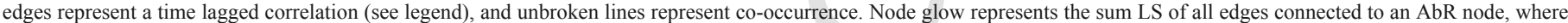

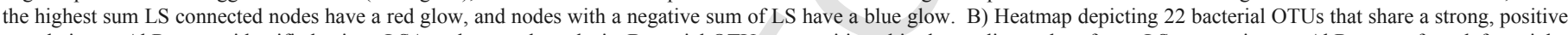

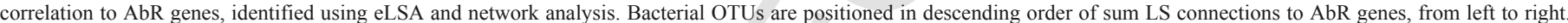

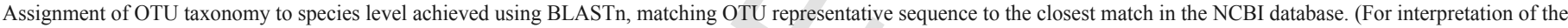
references to color in this figure legend, the reader is referred to the Web version of this article.)

storm-water input and modelled WWSO events, where 1-2 order of magnitude spikes in abundance occurred (Fig. 3). Infrequent spikes in $\mathrm{AbR}$ gene abundance associated with decreases in EC were observed at Maroubra Beach, particularly for $d f r A l$ and tetA (Fig. 4). However, at Foreshore Beach, where a substantially greater influence of storm-water input occurred (Fig. 1), spikes in AbR gene abundance were much more frequent and intense, with all five genes, including $\operatorname{van} B$, showing pronounced spikes in abundance, although notably these did not always coincide with each other (Fig. 4).

While the correspondence between AbR gene abundance and storm-water events was qualitatively clear (Fig. 4), we also observed a statistically significant co-occurrence between storm-water input and the concentration of all but one gene ( $\operatorname{vanB}$ ) (Supplementary Information Fig. 4). These immediate increases in AbR abundance during storm-water events are consistent with the concept that AbR genes are abundant and selected for in waste stream microbes (reviewed in (Rizzo et al., 2013)), which, as our bacterial community profile data above confirm, are washed into marine environments via storm-water outlets.

The tet $A$ gene confers resistance to tetracycline antibiotics, which are used widely in human and animal medicine as first line treatment and prophylactic control in a range of bacterial and protozoal infections (Chopra and Roberts, 2001; Schnappinger and Hillen, 1996). These antibiotics are also commonly detected in wastewater environments, and wastewater receiving environments (Lin et al., 2012).
Concentrations of tetA increased 10-fold above background levels at both Maroubra Beach and Foreshore Beach, with the highest concentrations detected during one storm-water event $\left(1.51 \times 10^{5}\right.$ gene copies $\mathrm{L}^{-1}$ ) and WWSO events (maximum peak of $8.11 \times 10^{4}$ gene copies $\mathrm{L}^{-1}$ ) at Foreshore Beach (Fig. 4), where statistically significant co-occurrence with storm-water and modelled WWSO events were detected $(\mathrm{p}<0.05)$ (Supplementary Information Fig. 4). Peaks in tet $A$ persisted during storm-water and modelled WWSO events, but generally returned to baseline concentrations within 7 days.

The sulI and $d f r A 1$ genes confer resistance to sulfonamides and trimethoprim, respectively (Huovinen et al., 1996), which are typically used in combination to treat common bacterial infections in humans (Stegeman et al., 1996). This is consistent with our observations of 10 -fold increases in the abundance of these genes above background concentrations during both storm-water-only and modelled WWSO events at Foreshore Beach (Fig. 4). Maroubra Beach experienced two peaks in $d f r A l$ and one peak in sulI abundance, however, only one of the $d f r A l$ peaks corresponded with a very modest drop in EC, while the others occurred during dry periods. Notably, sulI and $d f r A l$ displayed a statistically significant co-occurrence and 1 week time-lag with storm-water input events at Foreshore Beach $(\mathrm{P}<0.01$; Supplementary Information Fig. 5), indicating that elevated occurrence of these genes can persist in the environment for prolonged periods after an initial input event. 


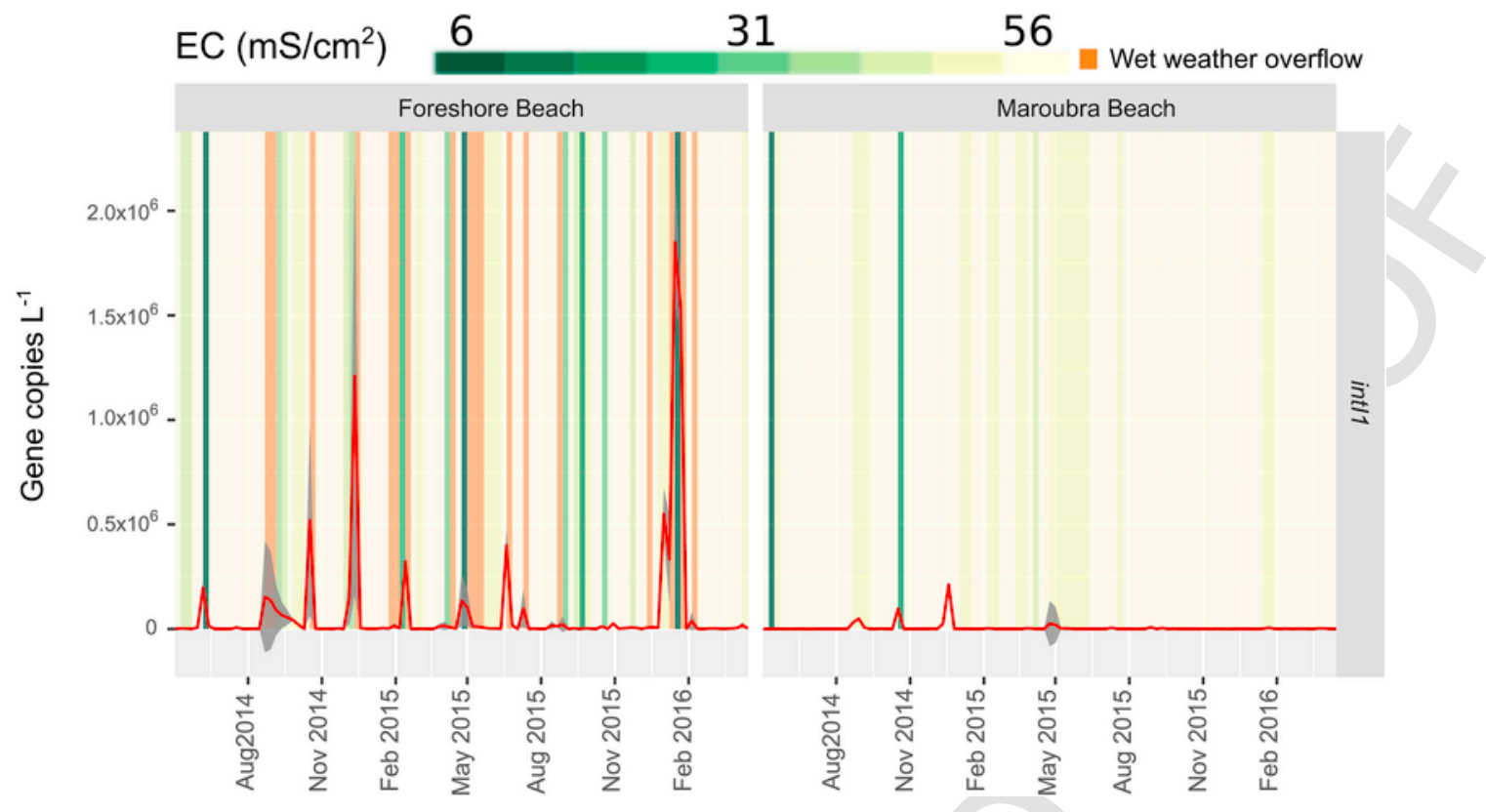

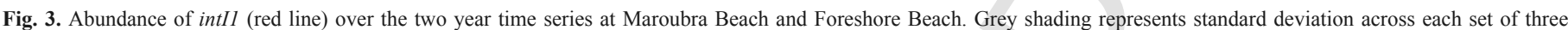

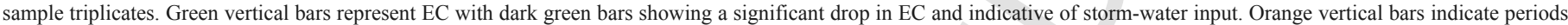

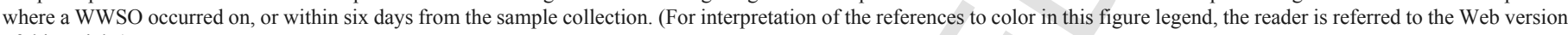
of this article.)

The qnrS gene confers non-susceptibility to quinolone antibiotics, which are used extensively in human and veterinary medicine, and are commonly detected in wastewater treatment plant (WWTP) influent and effluent (Karthikeyan and Meyer, 2006). The qnrS gene displayed a statistically significant co-occurrence with storm-water and modelled WWSO events $(\mathrm{P}<0.05)$. Increases of 10 -30-fold above background occurred during storm-water events and releases of WWSO, with gene abundance rising above $10^{4}$ gene copies $\mathrm{L}^{-1}$ on 11 occasions at Foreshore Beach, of which 4 co-occurred with storm-water-only input, while 7 co-occurred with sewer overflows, reaching a maximum peak of $2.0 \times 10^{6}$ (Fig. 4). The abundance of $q n r S$ peaked above $10^{5}$ on 3 occasions at Maroubra Beach, of which only one co-occurred in association with rainfall and runoff, with a maximum peak of $2.47 \mathrm{x}$ $10^{5}$ (Fig. 4). Peaks in $q n r S$ subsided one week after storm-water events at both sites and returned to background levels below $10^{4}$ gene copies $\mathrm{L}^{-1}$.

In contrast to the other $\mathrm{AbR}$ genes that were generally present across the entire time series, we detected the presence of vanB in only 4 of 104 sample occasions at Maroubra Beach, and 13 of 104 samples at Foreshore Beach (Fig. 4). vanB confers resistance to vancomycin, an important last resort treatment for multi-drug resistant Staphylococcus aureus (Koch et al., 2014; Roberts et al., 2009). The single, modest peak in $v a n B$ abundance at Maroubra Beach $\left(1.9 \times 10^{3}\right.$ gene copies $\mathrm{L}^{-1}$ ) occurred outside of storm-water input, and persisted for only 1 week (Fig. 4). Similarly, at Foreshore Beach, 11 small peaks in vanB abundance (relative to peaks seen in other AbR genes) occurred during dry periods. However, the two largest increases, each lasting one week, occurred during storm-water input (in the absence of WWSO) reaching concentrations of $2.67 \times 10^{4}$ and $1.57 \times 10^{4}$ (Fig. 3). The general lack of correlation between vanB occurrence and storm-water events is intriguing, allowing for the possibility of a co-selection process being responsible, however the source of input of this gene is currently unclear.

In addition to the direct quantification of five key AbR genes, a $\mathrm{mPCR} / \mathrm{RLB}$ hybridization approach, which has formerly only been applied to clinical bacterial isolates (Kong and Gilbert, 2006), was applied. This approach detected the presence of 7 out of 26 other genes associated with resistance to key antibiotics (Fig. 5), which encode for production of carbapenemase enzymes that are important for de-activation and resistance to clinically important carbapenems (Evans and Amyes, 2014; Poirel and Nordmann, 2006). Carbapenem antibiotics are particularly important medications in cases where limited therapy options exist for treatment of infections by multi-drug resistant bacteria (Nordmann et al., 2012; Poirel and Nordmann, 2006; WHO, 2017). The presence of OXA $\beta$-lactamases, including $\mathrm{OXA}_{-10} \mathrm{OXA}_{-48}$, correlated significantly with storm-water input $(\mathrm{LS}=-0.81, \mathrm{p}=<0.001$ and $\mathrm{LS}=0.51, \mathrm{p}=<0.001$ respectively), and modelled WWSO volume $(\mathrm{LS}=1.29, \mathrm{p}=<0.001$ and $\mathrm{LS}=0.74, \mathrm{p}=<0.001$ respectively), but $\mathrm{OXA}_{-23}$ or $\mathrm{OXA}_{-30}$, although detected on seven and three occasions respectively, did not correlate significantly with stormwater or modelled WWSO events. It should be noted that some carbapenems occur naturally in marine environments (Silber et al., 2016), so resistance to these compounds are expected to arise under natural selective pressure, albeit at low concentrations. Other genes that confer resistance to ß-lactam antibiotics, including $b l a_{\mathrm{TEM}}$ and $b l a_{\mathrm{VEB}}$, plus a carbapenemase gene $b l a_{\mathrm{VIM}}$, were also detected (Fig. 5), but at only one time point each. $b l a_{\mathrm{VIM}}$ occurred during a dry period, while $b l a_{\mathrm{VEB}}$ and $b l a_{\mathrm{TEM}}$ co-occurred with a storm-water input event. These observations are notable, given that detection of bla $a_{\mathrm{VIM}}$ and $b l a_{\mathrm{VEB}}$ outside of clinical environments is uncommon, perhaps due to the restricted application of some $\beta$-lactam antibiotics to curb rates of resistance (Gruson et al., 2000). However, this indicates that even when used at low levels, the degree of resistance to these antibiotics can still become elevated in the natural environment.

\subsection{Network analysis identifies potential bacterial vectors for antibiotic resistance genes}

Extended Local Similarity Analysis confirmed that the presence (and abundance in the case of the qPCR measured genes), of several 


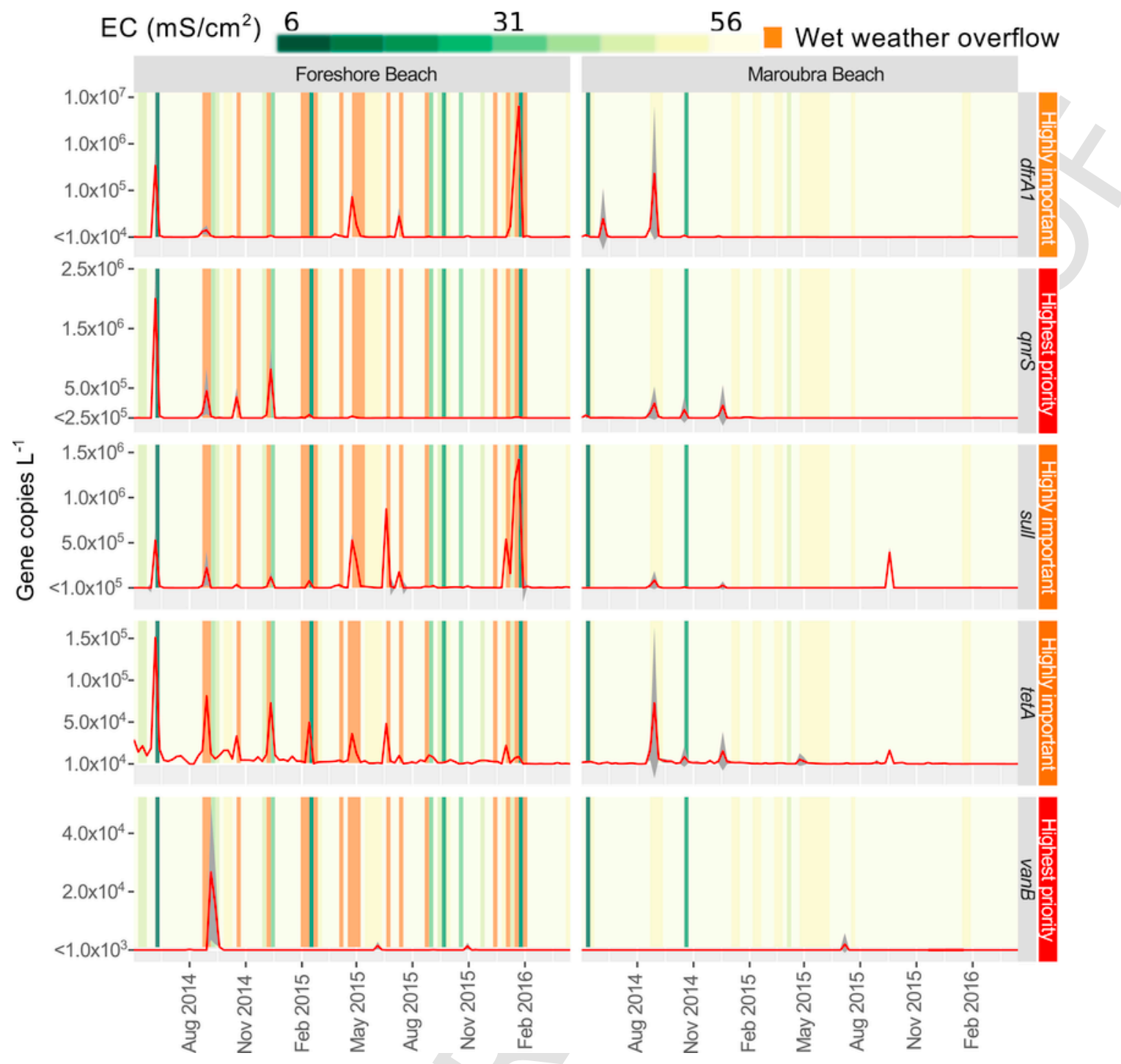

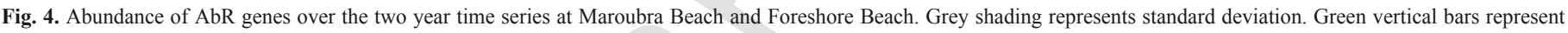

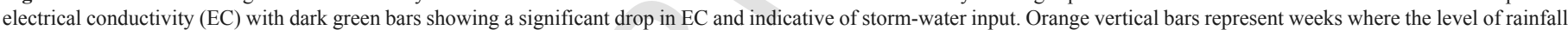
resulted in WWSO. (For interpretation of the references to color in this figure legend, the reader is referred to the Web version of this article.)

AbR genes was statistically linked to storm-water and modelled WWSO events. Specifically, qnrS, sulI and tetA concentration was significantly correlated with drops in EC, while $q n r S$ and sulI concentration was also correlated with the magnitude of modelled WWSO events (Fig. 2A). The correlations between storm-water and modelled WWSO events and increases in both bacterial diversity, abundance of AbR genes described and the abundance of bacterial genera commonly detected in waste stream microbial communities (McLellan et al., 2015) indicate that specific bacterial vectors are involved in the deposition of these genes in coastal environments. Storm-water and sewer overflow events will likely lead to the allochthonous input of both bacteria present within the source waters and those inhabiting storm-water and sewer pipe infrastructure (McLellan et al., 2015). Both groups are predicted to function as reservoirs for AbR genes and agents for their dissemination into coastal habitats (Millar and Raghavan, 2017).

The strongest positive correlation patterns occurred between AbR genes that confer resistance to quinolone ( $q n r S)$, carbapenem $\left(\right.$ bla $\left._{\mathrm{OXA}-48}\right)$ and $\beta$-lactam $\left(\right.$ bla $\left._{\mathrm{DHA}}\right)$ antibiotics, and 22 bacterial OTU's, of which 17 closely matched species common to sewage effluent and storm-water pipe infrastructure microbiomes (McLellan et al., 2013; Vandewalle et al., 2012) (Fig. 2B). The most prominent of these sewage and pipe bacterial groups include OTUs classified as Arcobacter nitrofigilis, Cloacibacterium repunse, Arcobacter butzleri, Arcobacter skirowi, Aeromonas caviacae and Acinetobacter johnsonii. Importantly, not all, but many bacteria belonging to these groups are also human pathogens, and have been implicated in multi-drug resistant, nosocomial and community borne infections (Douidah et al., 2012; Poirel and Nordmann, 2006). The culture-independent molecular methods used to identify these bacteria in this study do not confirm that these bacteria are in fact pathogenic strains. However, the patterns observed do support our proposition that the most likely vehicles for AbR flux into natural coastal habitats are bacteria associated with wastewater and those that live within the wastewater infrastructure environment (e.g. pipes). AbR genes from pipe sources present a significant, yet largely overlooked challenge for managing water quality and safety. This is because AbR genes may continue to be released into marine coastal environments after faecal indicator bac- 


\section{ECmSlcm || | || || || || |||| || || |||}

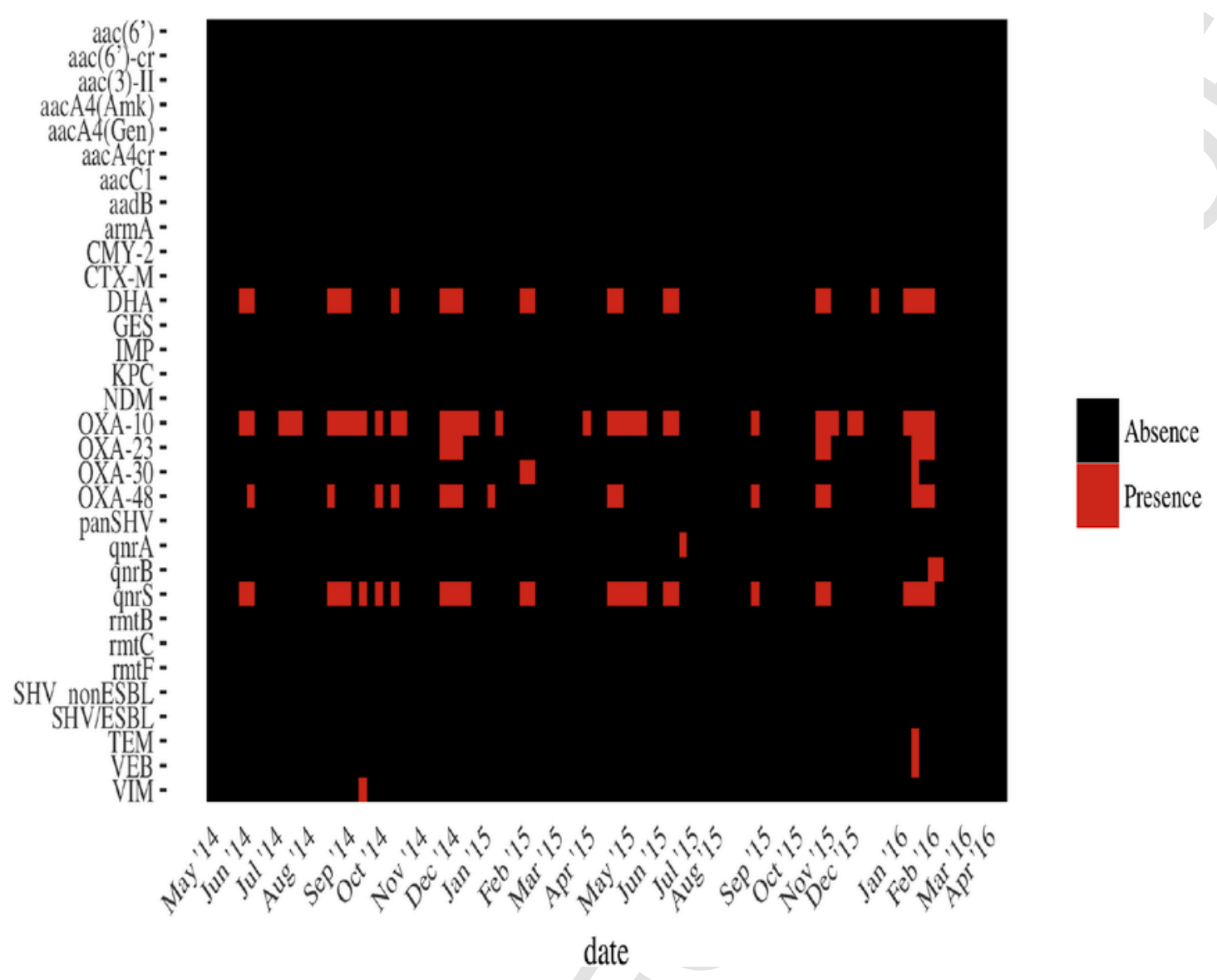

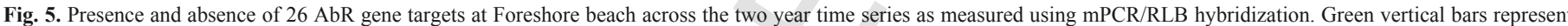

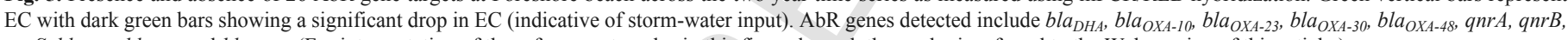
$q n r S, b l a_{T E M}, b l a_{V E B}$ and $b l a_{V I M}$. (For interpretation of the references to color in this figure legend, the reader is referred to the Web version of this article.)

teria, which are typically used as a proxy for contamination (Boehm and Sassoubre, 2014), have fallen below thresholds that trigger beach closure, potentially exposing water users to high concentrations of AbR genes, which may ultimately be assimilated into human microbiomes (Leonard et al. 2015, 2018).

\section{Conclusions}

By coupling culture-independent molecular approaches with a high temporal frequency sampling regime, this study has demonstrated that the occurrence and persistence of AbR genes in urban coastal habitats are closely linked to inputs of storm-water from an urban watershed, and modelled WWSO. Peaks in the abundance of clinically important AbR genes, including genes that confer resistance to both high usage front line antibiotics (e.g. quinolones, trimethoprim, sulfonamides and tetracycline), as well as last resort antibiotics (e.g. vancomycin, carbapenems), occurred in association with storm-water input and modelled WWSO events, whereby AbR gene abundances increased by 1-2 orders of magnitude over periods of 1-2 weeks. These observations strongly point to sewage and urban waste-stream infrastructure as potential reservoirs and conduits for the dissemination of AbR genes into coastal waters. Importantly, we have highlighted the role of storm-water and WWSO as a means for potentially pathogenic bacteria carrying AbR genes to cross habitat boundaries and augment the resistomes of coastal marine habitats. Thus, waste stream driven AbR in coastal waters poses a possible threat to human, animal and ecosystem health by: exposing users of coastal habitats to allochthonous AbR pathogens, facilitating the integration (e.g. through horizontal gene transfer) of AbR into the microbiomes of humans and marine animals, or leading to the assimilation of $\mathrm{AbR}$ by endemic marine pathogens.

\section{Author contributions}

R.L. Carney and J.R. Seymour conceived and designed the project. Sample collection and qPCR processing completed by R. L. Carney and N. Siboni. mPCR/RLB hybridization completed by R. L. Carney and K. A. Tagg. All authors contributed to the writing and editing of manuscript.

\section{Declaration of competing interest}

The authors declare that they have no known competing financial interests or personal relationships that could have appeared to influence the work reported in this paper. 


\section{Acknowledgements}

This study was funded by Australian Research Council project FT130100218 to J.R.S. We thank OEH Beachwatch for providing advice on sampling locations, and Sydney Water for making modelled WWSO data available.

\section{Appendix A. Supplementary data}

Supplementary data to this article can be found online at https:// doi.org/10.1016/j.watres.2019.115081.

\section{References}

Agyekum, A., Fajardo-Lubián, A., Ansong, D., Partridge, S.R., Agbenyega, T., Iredell, J.R., 2016. blaCTX-M-15 carried by IncF-type plasmids is the dominant ESBL gene in Escherichia coli and Klebsiella pneumoniae at a hospital in Ghana. Diagn. Microbiol. Infect. Dis. 84 (4), 328-333.

Anderson, M.J., 2001. A new method for non-parametric multivariate analysis of variance. Austral Ecol. 26 (1), 32-46.

Anderson, M., Gorley, R., Clarke, K., 2007. PERMANOVA+ for PRIMER: A Guide to Software and Statistical Methods. Primer-e, Plymouth, UK.

Baquero, F., Martinez, J.L., Canton, R., 2008. Antibiotics and antibiotic resistance in water environments. Curr. Opin. Biotechnol. 19 (3), 260-265.

Berglund, B., Khan, G.A., Lindberg, R., Fick, J., Lindgren, P.E., 2014. Abundance and dynamics of antibiotic resistance genes and integrons in lake sediment microcosms. PLoS One 9 (9), e108151.

Berglund, B., Fick, J., Lindgren, P.E., 2015. Urban wastewater effluent increases antibiotic resistance gene concentrations in a receiving northern European river. Environ. Toxicol. Chem. 34 (1), 192-196.

Boehm, A.B., Sassoubre, L.M., 2014. Enterococci as Indicators of Environmental Fecal Contamination, Massachusetts Eye and Ear Infirmary.

Bucci, J.P., Shattuck, M.D., Aytur, S.A., Carey, R., McDowell, W.H., 2017. A case study characterizing animal fecal sources in surface water using a mitochondrial DNA marker. Environ. Monit. Assess. 189 (8), 406.

Caporaso, J.G., Kuczynski, J., Stombaugh, J., Bittinger, K., Bushman, F.D., Costello, E.K., Fierer, N., Pena, A.G., Goodrich, J.K., Gordon, J.I., 2010. QIIME allows analysis of high-throughput community sequencing data. Nat. Methods 7 (5), 335-336.

Chamosa, L.S., Alvarez, V.E., Nardelli, M., Quiroga, M.P., Cassini, M.H., Centron, D., 2017. Lateral antimicrobial resistance genetic transfer is active in the open environment. Sci. Rep. 7 (1), 513.

Chopra, I., Roberts, M., 2001. Tetracycline antibiotics- mode of action, applications, molecular biology, and epidemiology of bacterial resistance. Microbiol. Mol. Biol. Rev. 65 (2), 232-260.

Chow, L., Waldron, L., Gillings, M.R., 2015. Potential impacts of aquatic pollutants: sub-clinical antibiotic concentrations induce genome changes and promote antibiotic resistance. Front. Microbiol. 6, 803.

Clark, G.F., Johnston, E.L., 2017. Australia State of the Environment 2016: Coasts, Independent Report to the Australian Government Minister for Environment and Energy. Australian Government Department of the Environment and Energy, Canberra.

Collier, S.A., Stockman, L.J., Hicks, L.A., Garrison, L.E., Zhou, F.J., Beach, M.J., 2012. Direct healthcare costs of selected diseases primarily or partially transmitted by water. Epidemiol. Infect. 140 (11), 2003-2013.

SECRC and Committee, S.E.a.C.R, 2015. Stormwater Management in Australia. SECRC, Canberra

Czekalski, N., Berthold, T., Caucci, S., Egli, A., Burgmann, H., 2012. Increased levels of multiresistant bacteria and resistance genes after wastewater treatment and their dissemination into lake geneva, Switzerland. Front. Microbiol. 3, 106

Decelle, J., Romac, S., Stern, R.F., Bendif, E.M., Zingone, A., Audic, S., Guiry, M.D., Guillou, L., Tessier, D., Le Gall, F., 2015. PhytoREF: a reference database of the plastidial 16S rRNA gene of photosynthetic eukaryotes with curated taxonomy. Mol. Ecol. Res. 15 (6), 1435-1445.

Douidah, L., de Zutter, L., Bare, J., De Vos, P., Vandamme, P., Vandenberg, O., Van den Abeele, A.M., Houf, K., 2012. Occurrence of putative virulence genes in arcobacter species isolated from humans and animals. J. Clin. Microbiol. 50 (3), $735-741$.

Edgar, R.C., Haas, B.J., Clemente, J.C., Quince, C., Knight, R., 2011. UCHIME improves sensitivity and speed of chimera detection. Bioinformatics 27 (16), 2194-2200.

Evans, B.A., Amyes, S.G., 2014. OXA beta-lactamases. Clin. Microbiol. Rev. 27 (2), 241-263.

Fisher, J.C., Levican, A., Figueras, M.J., McLellan, S.L., 2014. Population dynamics and ecology of Arcobacter in sewage. Front. Microbiol. 5, 525.
Foley, S.L., Lynne, A.M., 2008. Food animal-associated Salmonella challenges: pathogenicity and antimicrobial resistance. J. Anim. Sci. 86 (14 Suppl. 1), E173-E187.

Gillings, M., Boucher, Y., Labbate, M., Holmes, A., Krishnan, S., Holley, M., Stokes, H.W., 2008. The evolution of class 1 integrons and the rise of antibiotic resistance. J. Bacteriol. 190 (14), 5095-5100.

Gillings, M.R., Gaze, W.H., Pruden, A., Smalla, K., Tiedje, J.M., Zhu, Y.G., 2015. Using the class 1 integron-integrase gene as a proxy for anthropogenic pollution. ISME J. 9 (6), 1269-1279.

Ginn, A.N., Zong, Z., Wiklendt, A.M., Thomas, L.C., Merlino, J., Gottlieb, T., van Hal, S., Harkness, J., Macleod, C., Bell, S.M., Leroi, M.J., Partridge, S.R., Iredell, J.R., 2013. Limited diversity in the gene pool allows prediction of third-generation cephalosporin and aminoglycoside resistance in Escherichia coli and Klebsiella pneumoniae. Int. J. Antimicrob. Agents 42 (1), 19-26.

Gruson, D., Hilbert, G., Vargas, F., Valentino, R., Bebear, C., Allery, A., Bebear, C., Gbikpi-Benissan, G., Cardinaud, J.P., 2000. Rotation and restricted use of antibiotics in a medical intensive care unit: impact on the incidence of ventilator-associated pneumonia caused by antibiotic-resistant gram-negative bacteria. Am. J. Respir. Crit. Care Med. 162 (3), 837-843.

Haas, B.J., Gevers, D., Earl, A.M., Feldgarden, M., Ward, D.V., Giannoukos, G., Ciulla, D., Tabbaa, D., Highlander, S.K., Sodergren, E., 2011. Chimeric 16S rRNA sequence formation and detection in Sanger and 454-pyrosequenced PCR amplicons. Genome Res. 21 (3), 494-504.

Hardwick, S.A., Stokes, H.W., Findlay, S., Taylor, M., Gillings, M.R., 2008. Quantification of class 1 integron abundance in natural environments using real-time quantitative PCR. FEMS Microbiol. Lett. 278 (2), 207-212.

Hawkey, P.M., Jones, A.M., 2009. The changing epidemiology of resistance. J. Antimicrob. Chemother. 64 (Suppl. 1), i3-10.

Hehemann, J.H., Correc, G., Barbeyron, T., Helbert, W., Czjzek, M., Michel, G., 2010. Transfer of carbohydrate-active enzymes from marine bacteria to Japanese gut microbiota. Nature 464 (7290), 908-912.

Huovinen, P., Sundstro, L., Swedberg, G.t., Sköld, O., 1996. Trimethoprim and sulfonamide resistance. Antimicrob. Agents Chemother. 39 (2), 279-289.

Institute, D.H., 1999. MOUSE Ver. 1999 User Manual and Tutorial. Hørsholm, Denmark.

Karthikeyan, K.G., Meyer, M.T., 2006. Occurrence of antibiotics in wastewater treatment facilities in Wisconsin, USA. Sci. Total Environ. 361 (1-3), 196-207.

Koch, G., Yepes, A., Forstner, K.U., Wermser, C., Stengel, S.T., Modamio, J., Ohlsen, K., Foster, K.R., Lopez, D., 2014. Evolution of resistance to a last-resort antibiotic in Staphylococcus aureus via bacterial competition. Cell 158 (5), 1060-1071.

Koczura, R., Mokracka, J., Taraszewska, A., Lopacinska, N., 2016. Abundance of class 1 integron-integrase and sulfonamide resistance genes in river water and sediment is affected by anthropogenic pressure and environmental factors. Microb. Ecol. 72 (4), 909-916.

Kong, F., Gilbert, G.L., 2006. Multiplex PCR-based reverse line blot hybridization assay (mPCR/RLB)--a practical epidemiological and diagnostic tool. Nat. Protoc. 1 (6), 2668-2680.

Kuczynski, J., Stombaugh, J., Walters, W.A., Gonzalez, A., Caporaso, J.G., Knight, R., . Using QIIME to analyze 16S rRNA gene sequences from microbial communities. Curr Protoc Microbiol 27 (1), 2012, 1E-5.

Kummerer, K., 2009. Antibiotics in the aquatic environment--a review--part II Chemosphere 75 (4), 435-441.

Leonard, A.F., Zhang, L., Balfour, A.J., Garside, R., Gaze, W.H., 2015. Human recreational exposure to antibiotic resistant bacteria in coastal bathing waters. Environ. Int. $82,92-100$.

Leonard, A.F.C., Zhang, L., Balfour, A.J., Garside, R., Hawkey, P.M., Murray, A.K., Ukoumunne, O.C., Gaze, W.H., 2018. Exposure to and colonisation by antibiotic-resistant E. coli in UK coastal water users: environmental surveillance, exposure assessment, and epidemiological study (Beach Bum Survey). Environ. Int.

Lin, X., McKinley, J., Resch, C.T., Kaluzny, R., Lauber, C.L., Fredrickson, J., Knight, R., Konopka, A., 2012. Spatial and temporal dynamics of the microbial community in the Hanford unconfined aquifer. ISME J. 6 (9), 1665-1676.

Marchaim, D., Perez, F., Lee, J., Bheemreddy, S., Hujer, A.M., Rudin, S., Hayakawa K., Lephart, P.R., Blunden, C., Shango, M., Campbell, M.L., Varkey, J., Manickam, P., Patel, D., Pogue, J.M., Chopra, T., Martin, E.T., Dhar, S., Bonomo, R.A., Kaye, K.S., 2012. Swimming in resistance": Co-colonization with carbapenem-resistant Enterobacteriaceae and Acinetobacter baumannii or Pseudomonas aeruginosa. Am. J. Infect. Contr. 40 (9), 830-835.

Marti, E., Variatza, E., Balcazar, J.L., 2014. The role of aquatic ecosystems as reservoirs of antibiotic resistance. Trends Microbiol. 22 (1), 36-41.

McLellan, S.L., Newton, R.J., Vandewalle, J.L., Shanks, O.C., Huse, S.M., Eren, A.M., Sogin, M.L., 2013. Sewage reflects the distribution of human faecal Lachnospiraceae. Environ. Microbiol. 15 (8), 2213-2227.

McLellan, S.L., Fisher, J.C., Newton, R.J., 2015. The microbiome of urban waters. Int Microbiol. 18 (3), 141-149.

Michael, I., Rizzo, L., McArdell, C.S., Manaia, C.M., Merlin, C., Schwartz, T., Dagot, C., Fatta-Kassinos, D., 2013. Urban wastewater treatment plants as 
hotspots for the release of antibiotics in the environment: a review. Water Res. 47 (3), 957-995.

Michael, C.A., Dominey-Howes, D., Labbate, M., 2014. The antimicrobial resistance crisis: causes, consequences, and management. Front Public Health 2, 145.

Millar, J.A., Raghavan, R., 2017. Accumulation and expression of multiple antibiotic resistance genes in Arcobacter cryaerophilus that thrives in sewage. PeerJ 5, e3269.

Muziasari, W.I., Managaki, S., Parnanen, K., Karkman, A., Lyra, C., Tamminen, M., Suzuki, S., Virta, M., 2014. Sulphonamide and trimethoprim resistance genes persist in sediments at Baltic Sea aquaculture farms but are not detected in the surrounding environment. PLoS One 9 (3), e92702.

Nadkarni, M.A., Martin, F.E., Jacques, N.A., Hunter, N., 2002. Determination of bacterial load by real-time PCR using a broad-range (universal) probe and primers set Microbiology 148, 257-266.

Needham, D.M., Fuhrman, J.A., 2016. Pronounced daily succession of phytoplankton, archaea and bacteria following a spring bloom. Nat. Microbiol. 1, 16005.

Nordmann, P., Dortet, L., Poirel, L., 2012. Carbapenem resistance in enterobacteriaceae- here is the storm!. 18 (5), 263-272.

NSW Office of Environment and Heritage, 2015. State of the beaches 2014-2015. Heritage. In: In: N.O.o.E.a (Ed.), Beachwatch, Office of Environment and Heritage NSW

O'Neill, J., 2016. Tackling Drug-Resistant Infections Globally: Final Report and Recommendations.

Pehrsson, E.C., Tsukayama, P., Patel, S., Mejia-Bautista, M., Sosa-Soto, G., Navarrete, K.M., Calderon, M., Cabrera, L., Hoyos-Arango, W., Bertoli, M.T., Berg, D.E., Gilman, R.H., Dantas, G., 2016. Interconnected microbiomes and resistomes in low-income human habitats. Nature 533 (7602), 212-216.

Poirel, L., Nordmann, P., 2006. Carbapenem resistance in Acinetobacter baumannii: mechanisms and epidemiology. Clin. Microbiol. Infect. 12 (9), 826-836.

Rang, H.P., 2016. Rang \& Dale's Pharmacology E-Book : with STUDENT CONSULT Online Access. Churchill Livingstone, Philadelphia, PA?.

Rizzo, L., Manaia, C., Merlin, C., Schwartz, T., Dagot, C., Ploy, M.C., Michael, I., Fatta-Kassinos, D., 2013. Urban wastewater treatment plants as hotspots for antibiotic resistant bacteria and genes spread into the environment: a review. Sci. Total Environ. 447, 345-360.

Roberts, M.C., Soge, O.O., Giardino, M.A., Mazengia, E., Ma, G., Meschke, J.S., 2009. Vancomycin-resistant Enterococcus spp. in marine environments from the west coast of the USA. J. Appl. Microbiol. 107 (1), 300-307.

Robinson, T.P., Bu, D.P., Carrique-Mas, J., Fevre, E.M., Gilbert, M., Grace, D., Hay, S.I., Jiwakanon, J., Kakkar, M., Kariuki, S., Laxminarayan, R., Lubroth, J., Magnusson, U., Thi Ngoc, P., Van Boeckel, T.P., Woolhouse, M.E., 2016. Antibiotic resistance is the quintessential One Health issue. Trans. R. Soc. Trop. Med. Hyg. 110 (7), 377-380.

Sarmah, A.K., Meyer, M.T., Boxall, A.B., 2006. A global perspective on the use, sales, exposure pathways, occurrence, fate and effects of veterinary antibiotics (VAs) in the environment. Chemosphere 65 (5), 725-759.

Sauer, E.P., Vandewalle, J.L., Bootsma, M.J., McLellan, S.L., 2011. Detection of the human specific Bacteroides genetic marker provides evidence of widespread sewage contamination of stormwater in the urban environment. Water Res. 45 (14), 4081-4091.
Schnappinger, D., Hillen, W., 1996. Tetracyclines- antibiotic action, uptake, and resistance mechanisms. Arch. Microbiol. 165, 359-369.

Silber, J., Kramer, A., Labes, A., Tasdemir, D., 2016. From discovery to production: biotechnology of marine fungi for the production of new antibiotics. Mar. Drugs 14 (7).

Stegeman, C.A., Cohen Tervaert, J.W., de Jong, P.E., Kallenberg, C.G., 1996. Trimethoprim-sulfamethoxazole (co-trimoxazole) for the prevention of relapses of Wegener's granulomatosis. N. Engl. J. Med. 335 (1), 16-20.

Stewart, J.R., Gast, R.J., Fujioka, R.S., Solo-Gabriele, H.M., Meschke, J.S., Amaral-Zettler, L.A., Del Castillo, E., Polz, M.F., Collier, T.K., Strom, M.S., Sinigalliano, C.D., Moeller, P.D., Holland, A.F., 2008. The coastal environment and human health: microbial indicators, pathogens, sentinels and reservoirs. Environ. Health 7 (Suppl. 2), S3.

Sydney Water Corporation, 2015. Sewage Treatment System Impact Monitoring Program.

Taylor, N.G., Verner-Jeffreys, D.W., Baker-Austin, C., 2011. Aquatic systems: maintaining, mixing and mobilising antimicrobial resistance?. Trends Ecol. Evol. 26 (6), 278-284.

Tello, A., Austin, B., Telfer, T.C., 2012. Selective pressure of antibiotic pollution on bacteria of importance to public health. Environ. Health Perspect. 120 (8), $1100-1106$.

Turgeon, P., Michel, P., Levallois, P., Chevalier, P., Daignault, D., Crago, B., Irwin, R., McEwen, S.A., Neumann, N.F., Louie, M., 2011. Agroenvironmental determinants associated with the presence of antimicrobial-resistant Escherichia coli in beach waters in Quebec, Canada. Zoonoses Public Health 58 (6), 432-439.

Van Boeckel, T.P., Gandra, S., Ashok, A., Caudron, Q., Grenfell, B.T., Levin, S.A., Laxminarayan, R., 2014. Global antibiotic consumption 2000 to 2010: an analysis of national pharmaceutical sales data. Lancet Infect. Dis. 14 (8), 742-750.

Van Dyke, M.I., Morton, V.K., McLellan, N.L., Huck, P.M., 2010. The occurrence of Campylobacter in river water and waterfowl within a watershed in southern Ontario, Canada. J. Appl. Microbiol. 109 (3), 1053-1066.

Vandewalle, J.L., Goetz, G.W., Huse, S.M., Morrison, H.G., Sogin, M.L., Hoffmann, R.G., Yan, K., McLellan, S.L., 2012. Acinetobacter, Aeromonas and Trichococcus populations dominate the microbial community within urban sewer infrastructure. Environ. Microbiol. 14 (9), 2538-2552.

Wessa, P., 2017. Cross Correlation Function (v1.0.10) in Free Statistics Software (v1.2.1). Office for Research Development and Education.

WHO, 2017. Critically Important Antimicrobials for Human Medicine: Ranking of Antimicrobial Agents for Risk Management of Antimicrobial Resistance Due to Non-human Use. World Health Organization.

Witte, W., 1998. Medical consequences of antibiotic use in agriculture. Science 279 (5353), 996-997.

Wright, G.D., 2007. The antibiotic resistome: the nexus of chemical and genetic diversity. Nat. Rev. Microbiol. 5 (3), 175-186.

Wright, G.D., 2010. Antibiotic resistance in the environment: a link to the clinic? Curr. Opin. Microbiol. 13 (5), 589-594.

Xia, L.C., Steele, J.A., Cram, J.A., Cardon, Z.G., Simmons, S.L., Vallino, J.J., Fuhrman, J.A., Sun, F., 2011. Extended local similarity analysis (eLSA) of microbial community and other time series data with replicates. BMC Syst. Biol. 5 (2), S15. 